\title{
SOSTDC1 wt Allele
}

National Cancer Institute

\section{Source}

National Cancer Institute. SOSTDC1 wt Allele. NCI Thesaurus. Code C132098.

Human SOST DC1 wild-type allele is located in the vicinity of 7p21.2 and is approximately $69 \mathrm{~kb}$ in length. This allele, which encodes sclerostin domain-containing protein 1, plays a role in the modulation of bone morphogenic protein-dependent signaling pathways. 